\title{
225. výročí zrodu amerického dolaru aneb o české cestě vedoucí $k$ jeho názvu
}

\section{Vážení čtenáři,}

letos tomu bude 225 let od okamžiku, kdy Druhý kontinentální kongres ${ }^{1}$ vyhlásil na svém newyorském zasedání dne 6. července 1785 za měnovou jednotku Spojených států amerických jeden dolar. K samotnému vydání dolaru došlo však až o 7 let později na základě Mincovního zákona, Coinage Act, z 2. dubna 1792. Od této chvíle se americký dolar stal vším, čím se mohl stát. Pro některé lidi byl a je bohem, ke kterému se modlili a modlí, a jeho nabývání obětovali a obětují celý svůj život. Pro druhé představuje synonymum veškerého zla, jež může téměř za všechny lidské zločiny a jiné nectnosti. Pravda bude asi někde uprostřed obou názorů. Dolar je ve skutečnosti dobrý sluha, ale současně se může stát velmi špatným pánem.

Tohoto výročí bych, nicméně, rád využil k připomenutí české stopy ve slovu dolar. Pro tyto účely se musíme vrátit do začátku 16. století, kdy v Krušných Horách na panství rodu Šliků byla nalezena bohatá ložiska stříbrné rudy, a následně založena hornická osada s latinsko-německým názvem Sanctus Joachims Thal, v češtině Údoli svatého Jáchyma neboli dnešní Jáchymov. Na základě usilovného diplomatického jednání se Šlikům podařilo získat souhlas českého zemského sněmu z 9. ledna 1520 ke zř́zení soukromé mincovny, později následoval i souhlas českého krále Ludvíka Jagellonského. Svolení bylo uděleno k ražbě jednak pražských grošů podle kutnohorského vzoru, a jednak zlatníkových grošů podle vzoru saského. A právě zlatníkové groše získaly později označení podle místa svého vzniku, slovo tolar bylo odvozeno od staroněmeckého slova Thal (v dnešní němčině Tal).

Přiznejme si tedy, že slovo dolar je odvozeno z německého, nikoliv českého slova. Přesto však česká stopa $\mathrm{v}$ jeho názvu je zcela nesmazatelná. Tolary byly ražené na území tehdejšího českého království, dnešní České republiky, a to na základě svolení českého krále a českého zemského sněmu, přičemž na rubu mince byl zobrazen dvouocasý lev s korunou, coby český znak a uvedeno jméno vládnoucího českého krále.

K rychlému rozšíření tolarů po Svaté říši římské napomohlo současně několik faktorů. Především se jednalo o mince kvalitně ražené, jejichž hmotnost a ryzost kovu byla pečlivě hlídaná. Šlikové nebyli nuceni razit drobné mince, a mohli se soustředit na mince vyšší hodnoty. Zásluhou dobrého vztahu se saským dvorem získali př́stup na saský trh, hlavně pak na trh drahých kovů v Lipsku. Výnos byl použit mimo jiné pro splácení šlikovského dluhu v zahraničí, pro výplatu podílu dalších šlechtických rodů v Cechách, a paradoxně i pro nákup drobných stř́ibrných mincí na zajištění výplat horníkům a dalším zaměstnancům. V důsledku toho se tolary staly jedním z nejoblíbenějších platidel své doby.

Jak se tolary dostaly přes Atlantik až do Ameriky? Zásluhu na tom mají evropští osadníci, jež byli zvyklí označovat tímto slovem kvalitní stříbrné mince. V 18. století byly takovýmito mincemi dostupnými v Americe hlavně mexické osmirealy, a právě těmto mincím se začalo pro podobnou velikost a hmotnost s českými tolary říkat mexické dolary. Od toho byl již krok

1 Ford, W. C. (ed.) (1904-1937): Journals of the Continental Congress, Wednesday, July 6, 1785. [on-line], Washington, D. C., The Library of Congress, c2010, [cit. 10.5.2010],

<http://memory.loc.gov/cgi-bin/query/r?ammem/hlaw:@field(DOCID+@lit(jc0295))>. 
k tomu, aby Druhý kontinentální kongres za měnovou jednotku Spojených států amerických stanovil dolar, tedy označení běžně používané v té době pro nejkvalitnější mince na trhu.

Z mexického osmirealu pochází rovněž použivání symbolu „\$“ pro americký dolar. Na první pohled se sice zdá, že se jedná o pouhé svisle přeškrtnuté písmeno $\mathrm{S}$. Ve skutečnosti však tento symbol představuje Herkulův sloup. Na lícní straně španělské koloniální mince ražené v Mexiku byl pochopitelně portrét španělského krále, konkrétně v letech 1759 až 1788 to byl Karel III. Na rubové straně byl jednak královský znak a jednak dva Herkulovy sloupy, oba obtočené páskou označené nápisy Plus na levém a Ultra na pravém sloupu. Podle starých řeckých bájí a pověstí ${ }^{2}$ je postavil Herkules na své cestě při plnění jednoho $\mathrm{z}$ dvanácti úkolů, kdy měl z dalekého západu přihnat jakési stádo krav. Těmito sloupy by měly být dva skalní výběžky na obou stranách gibraltarské úžiny, Gibraltar na evropské a Jebel Musa na africké straně. Pro mnohé cestovatele z dávných dob představovaly Herkulovy sloupy konec světa, za nímž už žádného života není. Podle Platóna by však za nimi měla ležet ztracená Atlantida. Pro Kryštofa Kolumba se překonávání překážek a hledání nových zemí stalo výzvou, proto objevil Ameriku (tedy aspoň její ostrovní část). Španělský král Karel I. (vládl v letech 1516 až 1556) si právě na základě těchto nových zeměpisných objevů zvolil jako své osobní motto Plus Ultra (přeloženo z latiny Ještě dál), jež používal současně se zobrazením těchto sloupů. Jeho motto přetrvalo nakonec i na španělských mincích z 18. století. Američtí osadníci pak pro zjednodušení používali ve svých účetních záznamech symbol „\$“ nejdříve jako vyjádření počtu mexických osmirealů. A později se tento symbol uchytil i pro americký dolar. ${ }^{3}$

Co tedy popřát americkému dolaru při př́ležitosti výročí jeho vzniku? V souladu s nápisem na Herkulových sloupech, které používá jako svůj symbol, mu tedy popřejme Ještě dál, neboli Plus Ultra.

\author{
prof. Ing. Petr Marek, CSc. \\ předseda redakční rady Českého finančního a účetního časopisu \\ a řešitel výzkumného záměru \\ Rozvoj účetní a finanční teorie \\ a její aplikace v praxi z interdisciplinárního hlediska
}

2 Petiška, E.: Staré řecké báje a pověsti. Praha, SNDK, 1964.

3 Blíže o historii českého tolaru a vzniku amerického dolaru se lze dočíst v publikaci Vorel, P.: Od českého tolaru ke světovému dolaru. Český Těšín, Rybka Publishers, 2003. 